\title{
Internal structure of the buried Suwałki Anorthosite Massif (East European Craton, NE Poland) based on borehole, magnetic and gravity data combined with new petrological results
}

\author{
Zdzisław PETECKI ${ }^{1, *}$ and Janina WISZNIEWSKA ${ }^{1}$ \\ 1 Polish Geological Institute - National Research Institute, Rakowiecka 4, 00-975 Warszawa, Poland
}

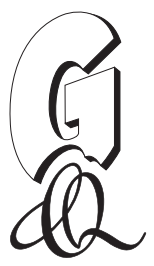

Petecki, Z, Wiszniewska, J, 2021. Internal structure of the buried Suwałki Anorthosite Massif (East European Craton, NE Poland) based on borehole, magnetic and gravity data combined with new petrological results. Geological Quarterly, 65: 4, doi: 10.7306/gq.1574

Associate Editor: Paweł Aleksandrowski

Advanced magnetic and gravity data analysis has been used to acquire geophysical constraints providing new insights into the geological structure of the Suwałki Anorthosite Massif (SAM). The large negative magnetic anomaly of the SAM anorthosite intrusion is a result of the negative inclination of remanent magnetization, directed antiparallel to the present Earth's magnetic field. Several filtering processes were applied to the magnetic and gravity maps to better understand the subsurface geology of the SAM area. The geological analysis of residual magnetic and gravity anomaly maps reveals the presence of different rock units, reflecting variation in petrological composition of the crystalline basement rocks. The 2-D modelling of magnetic and gravity data delineate the location and extent of the anorthosite-norite massif. The data is consistent with a thick upper crustal body with density $2690 \mathrm{~kg} / \mathrm{m}^{3}$, low susceptibility $(0.005 \mathrm{SI})$ and natural remanent magnetization $(1.95 \mathrm{~A} / \mathrm{m})$, having inclination of $\mathrm{I}=-68^{\circ}$, and declination of $D=-177^{\circ}$. The rocks bordering the central anorthosite body consist of norite and gabbronorite, granodiorite, diorite and charnockite. These main crystalline basement crustal units are shown more precisely on a new geological map of the SAM.

Key words: AMCG pluton, Suwałki Anorthosite Massif, potential field analysis, remanent magnetization, modeling of gravity and magnetic data, geological map.

\section{INTRODUCTION}

The Suwałki Anorthosite Massif (SAM) together with Sejny norite-anorthosite Intrusion (SI) belong to the magmatic anorthosite-mangerite-charnockite-granite (AMCG) set of rocks - a very common suite formed during Proterozoic time worldwide (Emslie, 1978, 1991; Ashval, 1993; Frost et al.,1989; Emslie et al., 1994; Bagiński et al., 2001; Wiszniewska, 2002; Wiszniewska et al., 2002, 2007; Skridlaite et al., 2003; Hamilton, 2004; Duchesne et al., 2010). Both massifs are located in the northeastern corner of Poland, near the border with Lithuania and Russia, building the western part of the East European Craton (Fig. 1A).

The SAM was discovered in 1957 (Znosko, 1993; Podemski, 1998) as a result of drilling into remarkable negative magnetic and gravity anomalies in NE Poland (Kurbiel et al., 1979). These investigations revealed the presence of anorthosite-norite rocks within the Precambrian crystalline basement,

\footnotetext{
* Corresponding author, e-mail: zdzislaw.petecki@pgi.gov.pl
} Received: May 11, 2020; accepted: November 6, 2020; first published online: February 2, 2021 concealed by thick Phanerozoic sedimentary rock sequences. The depth to the top of the SAM ranges from $\sim 600 \mathrm{~m}$ in the south to $1200 \mathrm{~m}$ in the west. Therefore, direct information on the nature and structure of the basement is limited to $~ 100$ unevenly distributed deep boreholes. However, most geological structures within the crystalline basement have distinctive magnetic and gravity signatures. Potential field anomaly analysis is, thus, a useful tool for investigating the subsurface structure of the SAM. Magnetic investigations have outlined the major structural features of the SAM. To a smaller degree, gravity anomaly interpretation has also been used (Podemski, 1998). Being a potential site of ore deposits, the SAM has long been studied geophysically, petrologically and structurally (e.g., Kurbiel et al., 1979; Cieśla and Wybraniec, 1998; Juskowiak, 1998; Cymerman, 2014). Despite previous geophysical and geological studies (Wybraniec et al., 1993; Ryka and Podemski, 1998; Wiszniewska, 2002; Wiszniewska et al., 2002, 2018) the composition and deep structure of the massif are still not well understood. The earlier geophysical interpretations were mainly used for practical purposes related to the large Fe-Ti-V mineral concentrations, and not for fundamental studies of variation in the internal structure of the SAM.

Therefore, this study provides a reinterpretation of the magnetic and gravity data to examine the arrangement of rock units of the SAM. A series of transformations and modeling of the 

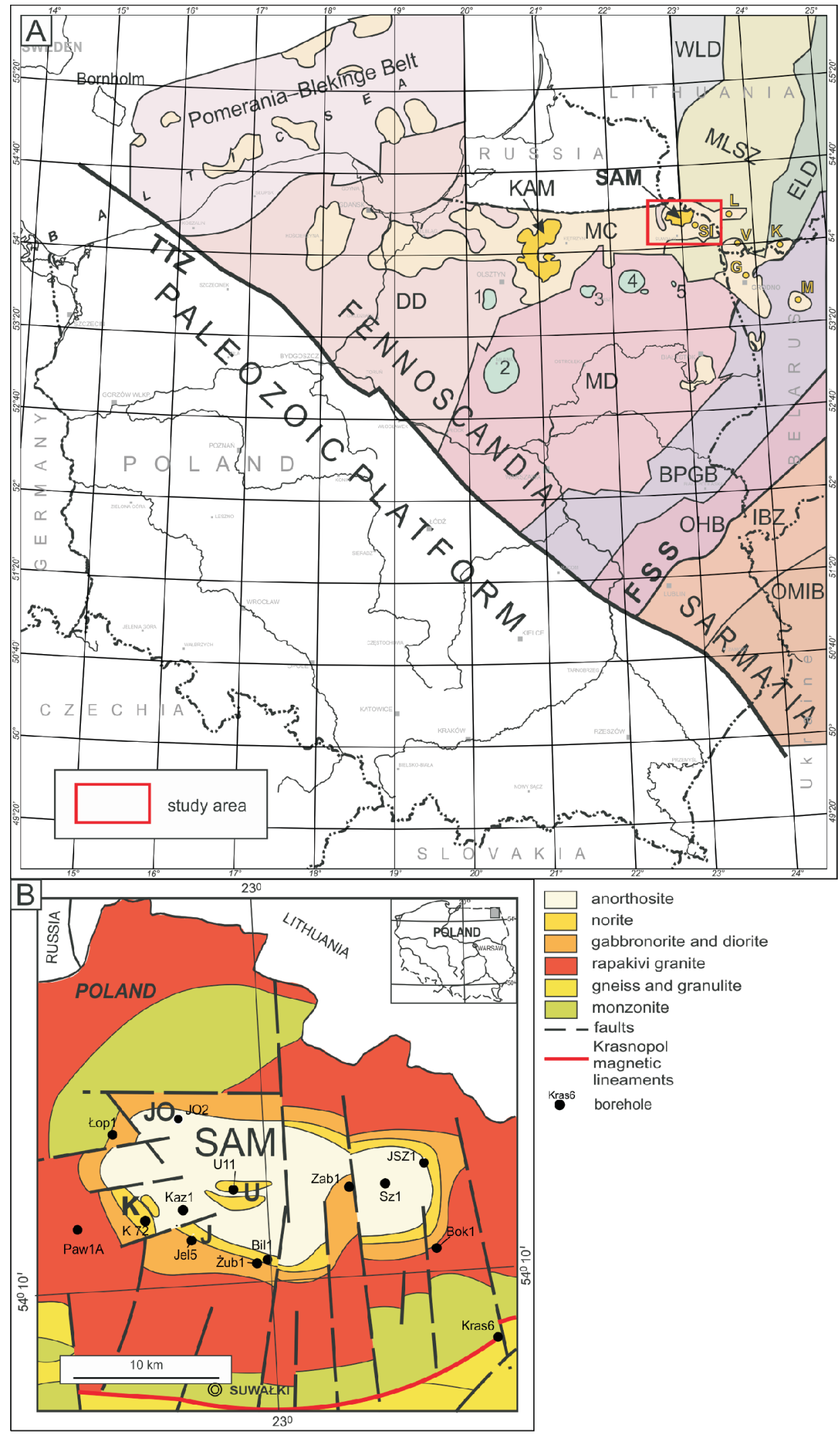

Fig. 1A - major crustal domains of crystalline basement in the Polish part of the East European Platform (after Krzemińska et al., 2017, modified); B - geological map of the Suwałki Anorthosite Massif (SAM; after Wiszniewska, 2002, modified)

Fault zones: TTZ - Teisseyre-Tornquist Zone, FSS - Fennoscandia-Sarmatia Suture; Crustal Domains: MC - Mazury Complex, MD Mazowsze Domain, DD - Dobrzyń Domain, MLSZ - Mid-Lithuanian Suture Zone, WLD - West Lithuanian Domain, ELD - East Lithuanian Domain, BPGB - Belarus-Podlasie Granulite Belt, OHB - Okolovo-Holeszów Belt, IBZ - Ivano-Borisov Zone, OMIB Osnitsk-Mikashevichi Igneous Belt; Mesoproterozoic massifs and intrusions: SAM - Suwałki Anorthosite Massif, KAM - Kętrzyn Anorthosite Massif, SI - Sejny Intrusion, L - Lazdijai Intrusion, V - Veisiejai Intrusion, K - Kabelia Intrusion, M - Mosty Intrusion, G - Grodno Intrusion; Paleozoic massifs and intrusions: 1 - Olsztynek, 2 - Mława, 3 - Pisz, 4 - Ełk, 5 - Tajno; boreholes penetrating the crystalline basement top lying at a depth of 600 to $1200 \mathrm{~m}$ : Bil1 - Bilwinowo PIG 1, Bok1 - Boksze PIG 1, Jel5 - Jeleniewo IG 5, JO2 - Jezioro Okrągłe IG 2, JSZ1 Jezioro Szlinokiemskie PIG 1, K72 - Krzemianka IG 72, Kaz1 - Kazimierówka IG 1, Kras6 - Krasnopol PIG 6, Łan1 - Łanowicze PIG-1, Łop1 - Łopuchowo PIG 1, Paw1A - Pawłówka PIG 1A, Sz1 - Szlinokiemie IG 1, U11 - Udryn IG 11, Żub1 - Żubryn IG 1; K, U, J, JO - Krzemianka, Udryn, Jeleniewo, Jezioro Okragłe ore fields 


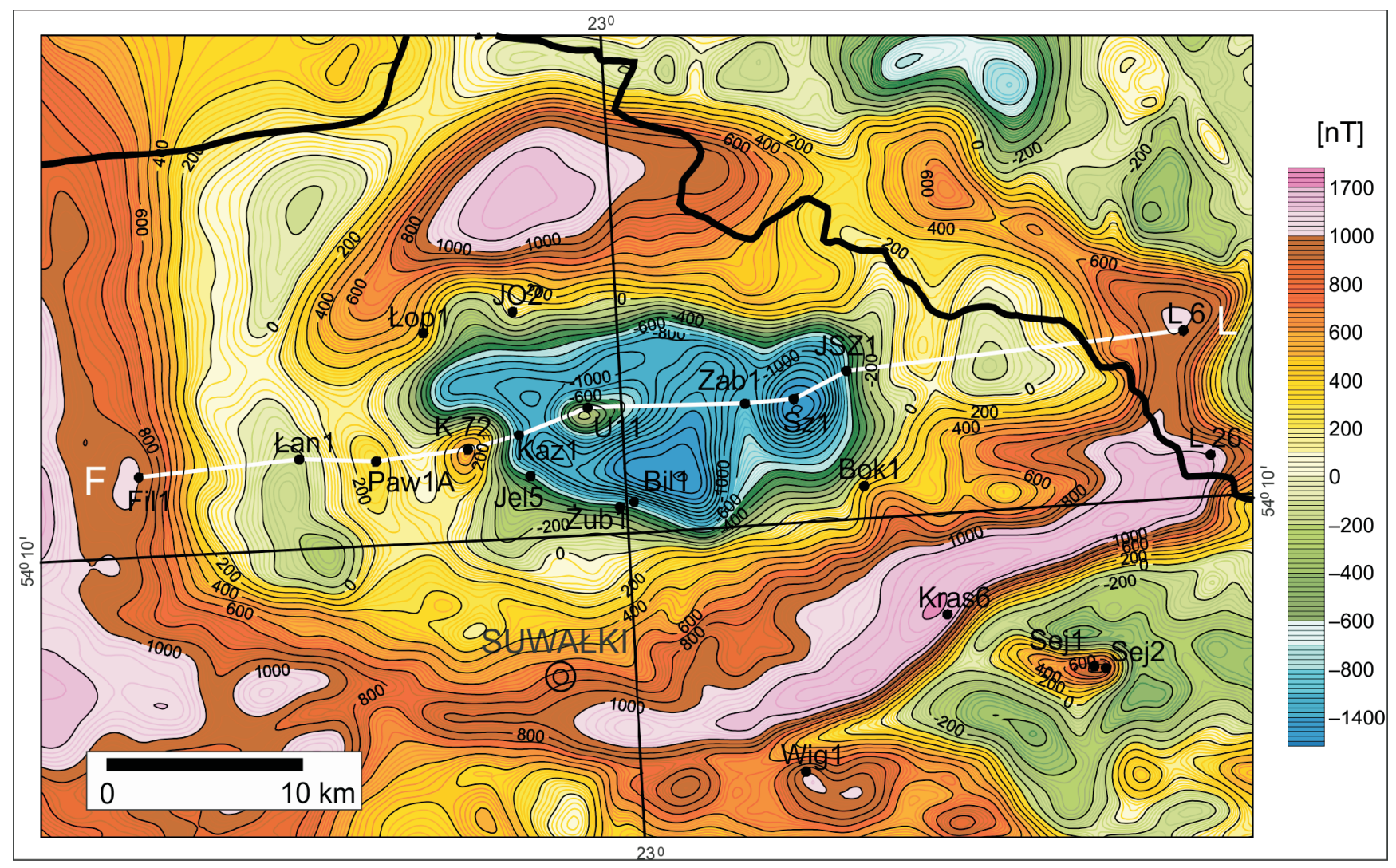

Fig. 2. Total intensity magnetic anomaly map of the Suwałki Anorthosite Massif (SAM) area, showing the location of F-L modelled profile

Boreholes penetrating the crystalline basement top: Bil1 - Bilwinowo PIG 1, Bok1 - Boksze PIG 1, Fil1 - Filipów IG 1, Jel5 - Jeleniewo IG 5 , JO2 - Jezioro Okrągłe IG 2, JSZ1 - Jezioro Szlinokiemskie PIG 1, K72 - Krzemianka IG 72, Kaz1 - Kazimierówka IG 1, Kras6 - Krasnopol PIG 6, L 6 - Lazdijai 6, L 26 - Lazdijai 26, Łan1 - Łanowicze PIG 1, Łop1 - Łopuchowo PIG 1, Paw1A - Pawłówka PIG 1 A, Sej1 - Sejny IG 1 , Sej2 - Sejny IG 2, Sz1 - Szlinokiemie IG 1, U11 - Udryn IG 11, Wig1 - Wigry IG 1, Żub1 - Żubryn IG 1; F-L - profile used for gravity and magnetic modelling

magnetic and gravity data were used for interpretation and geological correlation. Most notably, these included estimation of the remanent magnetization direction of the SAM anorthosite complex, as the direction of magnetization may problematic in interpreting the magnetic anomaly map. Recognition of the geometry and internal structure of the massif, and constraining the nature of the anorthosite contacts with the adjacent rocks, were the main issues to be resolved using modern geophysical interpretation.

\section{GEOLOGICAL AND GEOPHYSICAL SETTING}

The crystalline basement of NE Poland and neighbouring countries as Russia, Lithuania and Belarus, is characterized by a set of belt-shaped tectonic metamorphic domains formed mostly in Paleoproterozoic time (Bogdanova et al., 2015) and cut later by Mesoproterozoic igneous intrusions (Bogdanova et al., 2006, 2015). The SAM and SI are a part of wider, belt-like, $\mathrm{E}-\mathrm{W}$ trending, $300 \mathrm{~km}$ long Mesoproterozoic magmatic terrane (1.54-1.49 Ga), called the Mazury igneous Complex (MC, Fig. 1A), that is composed of granitoids (rapakivi-like), charnockites and mangerites (Bagiński et al., 2001; Wiszniewska et al., 2007; Krzemińska et al., 2019). Quartz monzonites and granodiorites are the most widespread rock type within this belt. The continuation of the Mazury Complex in Lithuania comprises the Lazdijai (L), Veisiejai (V) and Kabeliai (K) intrusions (Skridlaite et al., 2003), and the Mosty (M) and
Grodno (G) intrusions in Belarus (Taran, 2005; Fig. 1A). The MC magmatic rock assemblages belong to the ferro-potassic, alkali-calcic suite of rocks and are comparable with other AMCG rock types from Fennoscandia, e.g. Rogaland, southern Norway (Duchesne, 1999). The most acidic varieties of MC and Veisiejai $(V)$ granitoids have petrogenetic properties similar to those of classic rapakivi granites, though they show an increased content of incompatible elements and REE, typical for A type affinities (Gawęda et al., 2009; Duchesne et al., 2010).

The MC magmatic rocks intruded into deep tectonic crustal structures within Paleoproterozoic metamorphic domains that belong to the Middle Lithuanian Suture Zone (MLSZ) and the West Lithuanian Domain (WLD) and its southern Polish extension as the Dobrzyń Domain (DD) and the Mazowsze Domain (MD) that were accreted at $1.85-1.80 \mathrm{Ga}$ (Bogdanova et al., 2006). A much younger, Carboniferous, $E-W$ trending chain of alkaline sub-platform intrusions include those of Olsztynek (1), Mława (2), Pisz (3), Ełk (4) and Tajno (5), on the southern boundary of the $\mathrm{MC}$, have also been recognized (Demaiffe et al., 2013; Wiszniewska et al., 2020).

Drilling of $\sim 100$ boreholes has shown that the SAM of $1.5 \mathrm{Ga}$ age covers an areal extent of $\sim 250 \mathrm{~km}^{2}$ (Wiszniewska et al., 2002). This Mesoproterozoic massif is essentially made up of magmatic massif-type anorthosite (with local titanomagnetite ore concentrations), surrounded by rings of norite and gabbronorite (Kubicki and Ryka, 1982), diorite, rapakivi-like granite and monzonite (Fig. 1B; Wiszniewska et al., 2002). 


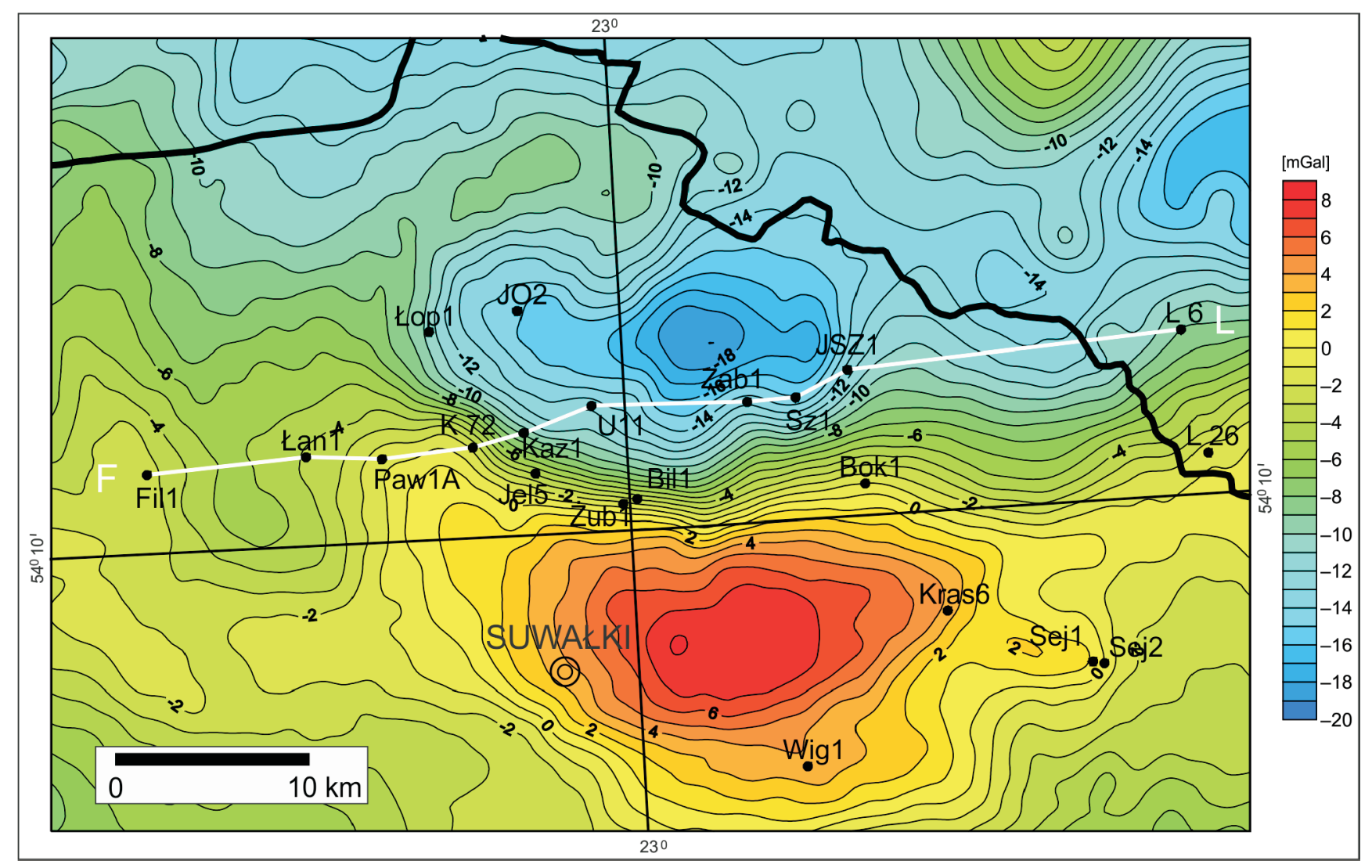

Fig. 3. Bouguer gravity anomaly map of the Suwałki Anorthosite Massif (SAM) area

Explanations as in Figure 2

The Fe-Ti-V large ore deposits of the Krzemianka $(\mathrm{K})$ and Udryn $(U)$ ore fields and two other smaller bodies, Jeleniewo (J), Jezioro Okraggłe (JO; Fig. 1B), concentrated in the marginal parts of the massif, have been documented within anorthosites, norites, and gabbronorites (Wiszniewska, 1998a, 2002; Wiszniewska et al., 2018). Titanomagnetite, ilmenite and Fe-Cu-Co-Ni sulphides are the main ore minerals in the host rocks. Magnetic titanomagnetite grains usually contain networks of narrow ilmenite and ulvite lamellae (Mizeracka and Kurbiel, 1973, 1975).

Magnetic and gravity maps of the SAM, with locations of selected boreholes, are shown in Figures 2 and 3. The SAM appears mainly as large negative, magnetic $(-1700 \mathrm{nT})$ and gravity $(-19 \mathrm{mGal})$ anomalies that are similar in size and shape (Królikowski and Petecki, 1995; Królikowski et al., 1998; Petecki and Rosowiecka, 2017). According to the geological data these anomalies are related to the large monomineralic anorthosite body in the centre of the SAM (Juskowiak, 1998). The local positive magnetic anomaly near the Zaboryszki 1 (Zab1) borehole, related to the diorite body, divides the magnetic depression into two parts.

The large negative magnetic anomaly is surrounded by a high gradient zone and bands of positive anomalies with significant amplitudes of $\sim 800-1700 \mathrm{nT}$, particularly strongly marked in the south, west and north (Fig. 2). One of the most striking magnetic features is a magnetic gradient zone (called here the Krasnopol magnetic lineament) in the vicinity of the Krasnopol PIG 6 (Kras6) borehole, bounding the southern massif margin along a curvilinear contact between monzonites and granodiorites (rapakivi-like granites) in the north and gneisses and granulites in the south (Fig. 1B). Local positive magnetic anomalies are related to the Krzemianka and Udryn ore deposits ( $K$ and $U$ in Fig. 1). In the southeastern corner of the map (Fig. 2) an isolated magnetic high reflects the small Sejny norite-gabbronorite-monzodiorite Intrusion (SI).

The Bouguer gravity map of the SAM (Fig. 3) shows two distinct regional anomalies: a negative anomaly with an intensity of $-19 \mathrm{mGal}$ related to the relatively low-density central anorthosite body, and positive anomalies with a maximum intensity of $8 \mathrm{mGal}$ surrounding the massif to the south and west, caused by rocks with elevated densities. These two anomalies are separated by a high gradient zone. The Fe-Ti-V ore deposits are not very well marked on the Bouguer gravity anomaly map. Also, the Krasnopol magnetic lineament does not appear to be reflected on this map.

Various geological maps of the SAM (Kubicki and Ryka, 1982; Juskowiak, 1998; Wiszniewska, 2002; Cymerman, 2014; Krzemińska et al., 2017) have been made based mainly on the results of geophysical research, primarily magnetic data analyses integrated with borehole data. Most of the SAM area was not recognized by boreholes, because geological investigations were focused on prospecting for magnetite-ilmenite ore deposits (Wiszniewska et al., 2018). Therefore, the geological map of the SAM, beyond well identified areas of the Krzemianka and Udryn deposits, remains tentative.

\section{MATERIALS AND METHODS}

The results shown in this paper are mainly based on potential-field filtering and modelling using existing magnetic and gravity data. 


\section{MAGNETIC DATA}

The magnetic data is represented by a total magnetic intensity anomaly map (Fig. 2). The total-field magnetic anomaly was obtained by subtracting the magnitude of an appropriate DGRF (Definitive Geomagnetic Reference Field) 1982.5 regional field from the total field measurement (Petecki and Rosowiecka, 2017).

\section{GRAVITY DATA}

The gravity data are represented by a simple Bouguer anomaly map (Fig. 3). The gravity data were tied to the gravity datum based on the IGSN 71 (International Gravity Standardization Net of 1971). The Bouguer anomalies have been calculated using a reduction density of $2250 \mathrm{~kg} / \mathrm{m}^{3}\left(2.25 \mathrm{~g} / \mathrm{cm}^{3}\right)$ and the GRS 80 (Geodetic Reference System of 1980) formula for the theoretical gravity (Królikowski and Petecki, 1995).

\section{ROCK PROPERTY DATA}

Density and magnetic property measurements of the crystalline basement rocks from the SAM were made on unoriented core rock samples from the boreholes (Mizeracka and Kurbiel, 1973; Kurbiel at al., 1979). Results from these measurements are also given by Mizeracka and Kurbiel (1975), Wybraniec et al. (1993), Cieśla and Wybraniec (1998).

\section{DENSITY DATA}

The density of the anorthosites that compose the main part of the SAM ranges between 2690 and $2770 \mathrm{~kg} / \mathrm{m}^{3}$, with an average density of $2720 \mathrm{~kg} / \mathrm{m}^{3}$ (Cieśla and Wybraniec, 1998). However, in the Kazimierówka IG 1 (Kaz1) and Szlinokiemie IG 1 (Sz1) boreholes which drilled only anorthosites, their density is $2690 \mathrm{~kg} / \mathrm{m}^{3}$. Mineralized parts of anorthosites show higher densities. The density of rocks directly bordering the central anorthosite masses, i.e. norites and gabbronorites, is distinctly higher $\left(3000 \mathrm{~kg} / \mathrm{m}^{3}\right)$ than that of the anorthosites. Densities of the rapakivi granites and diorites surrounding the anorthosite complex oscillate between 2750 and $2910 \mathrm{~kg} / \mathrm{m}^{3}$ (Wybraniec et al., 1993; Cieśla and Wybraniec, 1998).

\section{MAGNETIC PROPERTY DATA}

Magnetic property data of basement rocks from the SAM reflect the presence of magnetic minerals, mainly titanomagnetite, ilmenite or hemoilmenite, magnetite, or maghemite (Mizeracka and Kurbiel, 1973, 1975). The magnetic susceptibility of anorthosites with small amounts of ore minerals is low on average $(0.009 \mathrm{SI})$. The susceptibilities of anorthosites, norites and gabbronorites with magnetite-ilmenite mineralization, and of ore bodies, are strongly variable and reach up to $2.0 \mathrm{SI}$ for ores

The ratio of the intensity of remanent magnetization (NRM) to induced magnetization, termed the Koenigsberger coefficient or $Q$ value, in anorthosites is commonly $>1$, and ranges from $\sim 5$ up to 30 . The inclination of the NRM of the anorthosite rocks showed very variable directions, usually with positive values. By contrast, the NRM inclinations of the magnetite-ilmenite ores and noritic rocks are characterized by predominantly negative values and shown considerable scatter (Mizeracka and Kurbiel, 1973, 1975; Kurbiel et al., 1979). The variability of magnetic properties within the rock types makes it difficult to reliably esti- mate the average susceptibility, NRM and direction of magnetization values of the buried rocks.

\section{BOREHOLE DATA}

Most of the boreholes, of average $2000 \mathrm{~m}$ depth, were drilled within the SAM area between the 1950s and 1990s to document the Fe-Ti-V deposits of the Krzemianka and Udryn areas (Kubicki and Siemiątkowski, 1979; Parecki, 1998). New whole-rock samples from the Krzemianka, Udryn, and Jezioro Okrągłe ore field areas and individual boreholes within other parts of the SAM e.g. Łopuchowo IG 1 (Łop1), Biliwinowo IG 1 (Bil1), Jeleniewo IG 5 (Jel5), Jezioro Szlinokiemskie IG 1 (JSZ1), Zaboryszki IG 1 (Zab1), were additionally analysed for major and some trace elements in 2016-2020 in the laboratory of the Polish Geological Institute - National Research Institute (PGI-NRI). Major elements were analysed using ICP-ES and trace elements were analysed using ICP-MS. Chemical data, together with petrological, U-Pb SHRIMP dating and structural results on rock samples, have been assembled for the various lithologies that built the SAM via magmatic processes. All rock types display complex and temporally ambiguous relationships throughout the massif, and they have been studied recently in detail together with geophysical data, for production of a new geological map.

\section{DATA PROCESSING}

In examining the internal structure of the SAM, this paper has re-analysed existing magnetic and gravity data. On magnetic data the pseudogravity and reduction to the pole (RTP) methods were applied. The pseudogravity transformation was used to compare magnetic with gravity data to determine the direction of magnetization of the anorthosite complex (Ates and Kearey, 1995). The RTP transformation was used to recalculate the magnetic anomaly into the anomaly that would be observed at the north magnetic pole (Baranov, 1957; Baranov and Naudy, 1964). This procedure facilitates the interpretation of the data.

A radial power spectrum analysis was applied to both magnetic and gravity data to estimate the regional and residual components of the spectrum related to shallow and deep sources. The wavelength filtering methods were applied to the RTP magnetic and gravity maps to obtain the regional and residual anomaly fields. However, the data processing generally focused on enhancement of the short wavelength (residual) features, that is more suitable for high-resolution mapping of crystalline basement.

Besides map processing, the modeling of gravity and magnetic data along the profile was carried out to investigate the relation between the potential field anomalies and the borehole geology. Finally, a new geological map was prepared to illustrate the main crustal units of the SAM.

\section{POTENTIAL FIELD INTERPRETATION MAGNETIC DATA TRANSFORMATION}

Using magnetic data in geological interpretation is difficult since magnetic anomalies usually do not lie directly above their causative sources. Displacement between anomalies and their sources results from different directions of the geomagnetic field of the area and source magnetization, which are not vertical beyond the magnetic poles (Blakely, 1995). To correct for 
this distortion, the magnetic data should be transformed to a pseudogravity field or reduced to the pole by the application of mathematical filters to the observed data (Baranov, 1957; Baranov and Naudy, 1964). In these techniques the total magnetization vector (which is the vector sum of the induced and remanent magnetizations) is made vertical. The magnetic interpretation becomes simpler since these transformations shift the anomalies over their causative sources.

Because the magnetization vector is usually unknown, induced magnetization for pseudogravity or reduction to the pole transformations is assumed. The assumption means that the remanent magnetization is either weak or aligned parallel to the ambient field. This approach would lead to an incorrect result of magnetic data interpretation if the remanent magnetization of the source exceeds the induced magnetization, and if the directions of the remanent and induced magnetization are different. In this case the total magnetization vector can cause negative magnetic anomalies, such as the ones corresponding with the central anorthosite complex of the SAM. Therefore, knowledge of the accurate direction of the source magnetization is important to interpreting the magnetic anomalies.

\section{PSEUDOGRAVITY TRANSFORMATION AND DIRECTION OF MAGNETIZATION OF THE CENTRAL ANORTHOSITE COMPLEX OF THE SAM}

Since the large negative magnetic anomaly associated with the central anorthosite complex of the SAM cannot be explained with the presence of a source with induced magnetization only, it is inferred that this anomaly reflects an effect of negative remanent magnetization of anorthosite rocks considerably exceeding the induced magnetization, although the carriers of remanence are not well documented (Mizeracka and Kurbiel, 1973, 1975; Cieśla and Wybraniec, 1998). This hypothesis is also supported by magnetic modeling (Petecki, 2006) along the regional refraction and wide-angle reflection POLONAISE'97 seismic profile P4 that cross-cuts the SAM (Grad et al., 2003). However, existing measurements do not show prevailing negative inclinations of remanent magnetization of the anorthosite (Mizeracka and Kurbiel, 1973, 1975). Because these measurements were made on samples from boreholes mostly located within the ore bodies, they may not be representative.

Pseudogravity transformation, first introduced by Baranov (1957), follows from Poisson's relation between the magnetic scalar potential and the component of the gravity field in the direction of magnetization, and is defined as the gravity anomaly that would be observed if the magnetization distribution were replaced by an identical density distribution.

A method which compares the observed gravity anomaly and the pseudogravity transformation of the measured magnetic anomaly (Ates and Kearey, 1995) was used here for testing the direction of magnetization of the central anorthosite complex of the SAM. The method assumes that the source of the gravity and magnetic anomalies is the same. To apply the pseudogravity transformation it is necessary to know the direction of magnetization. When the pseudogravity anomaly is calculated using the correct values of inclination and declination of the total magnetization, the correlation between the observed gravity and the calculated pseudogravity anomaly is greatest.

Taking into account the absence of reliable information on the remanent magnetization direction, the magnetic data (Fig. 2) were transformed by the pseudogravity transformation assuming the average direction of total magnetization of most rocks to be parallel or anti-parallel to the Earth's main field (inclination $=68^{\circ}$, declination $=3^{\circ}$ for the study area). The resulting pseudogravity anomaly map is shown in Figure 4. The comparison between the pseudogravity and the gravity anomaly map (Fig. 5) yields a relatively good correlation between magnetic and gravity sources. The minimum of the pseudogravity anomaly and that of the gravity anomaly are both situated over the central anorthosite complex indicating that both the gravity and magnetic anomalies are due to the same crustal unit that has substantial remanent magnetization aligned antiparallel to the ambient magnetic field. Other gravity and pseudogravity anomalies also have similar shapes.

From this pseudogravity analysis it can be concluded that most of the intrusive rocks in the SAM complex are magnetized approximately along the present direction of the Earth's magnetic field or along the opposite direction. Nevertheless, if the present magnetization of the source differs from this direction at a specific location, the source position will be slightly shifted from the maximum of the magnetic anomaly. This should not significantly change the main results of present study.

The coincident patterns in the gravity and pseudogravity fields support the interpretation that the central anorthosite complex of the SAM is a coherent crustal unit. However, the term pseudogravity does not imply that the source magnetization is necessarily related to a source density. According to Szewczyk (2017) the gravity anomaly low over the SAM is associated with the very low densities of the sedimentary rocks related to both the present-day permafrost thickness (revealed in one borehole) and the process of density recompaction in the near-surface part over the anorthosite complex. Therefore, the question arises whether there is a density contrast between the central anorthosite complex and the surrounding basement rocks. The earlier discussion of rock densities shows that most of the rocks have higher densities than those of the central anorthosite complex of the SAM, pointing to the same source for magnetic and gravity anomalies. However, the low density of the permafrost undoubtedly has an impact on the image of residual gravimetric anomalies at some specific locations.

\section{REDUCTION TO THE POLE OF MAGNETIC DATA}

The RTP transformation converts the measured magnetic anomaly to an anomaly that would be measured at the north magnetic pole, where the geomagnetic field and the respective induced magnetization vector is vertical (Baranov, 1957; Baranov and Naudy, 1964). The RTP transformation shifts the anomaly laterally to be centered over the source of the anomaly, making the magnetic anomaly easier to interpret. However, when strong remanent magnetization is also present and is poorly constrained, the transformation may produce incorrect anomalies. Just like in the case of the pseudogravity transformation, the RTP transformation requires an assumption about the directions of magnetization of the magnetic sources. According to the above result of pseudogravity analysis of magnetic anomalies over the SAM, it was assumed that the magnetization vector of the rocks was parallel (or anti-parallel) to the ambient magnetic field.

The resulting RTP map is shown in Figure 6. Reduction to the pole, in comparison with the original total intensity magnetic map (Fig. 2), results in a northward migration of the magnetic anomalies, due to the elimination of the inclination and declination of the magnetic field at this area. The positive and negative magnetic anomalies formerly described in the total intensity magnetic map (Fig. 2) are well defined on the RTP map (Fig. 6). 


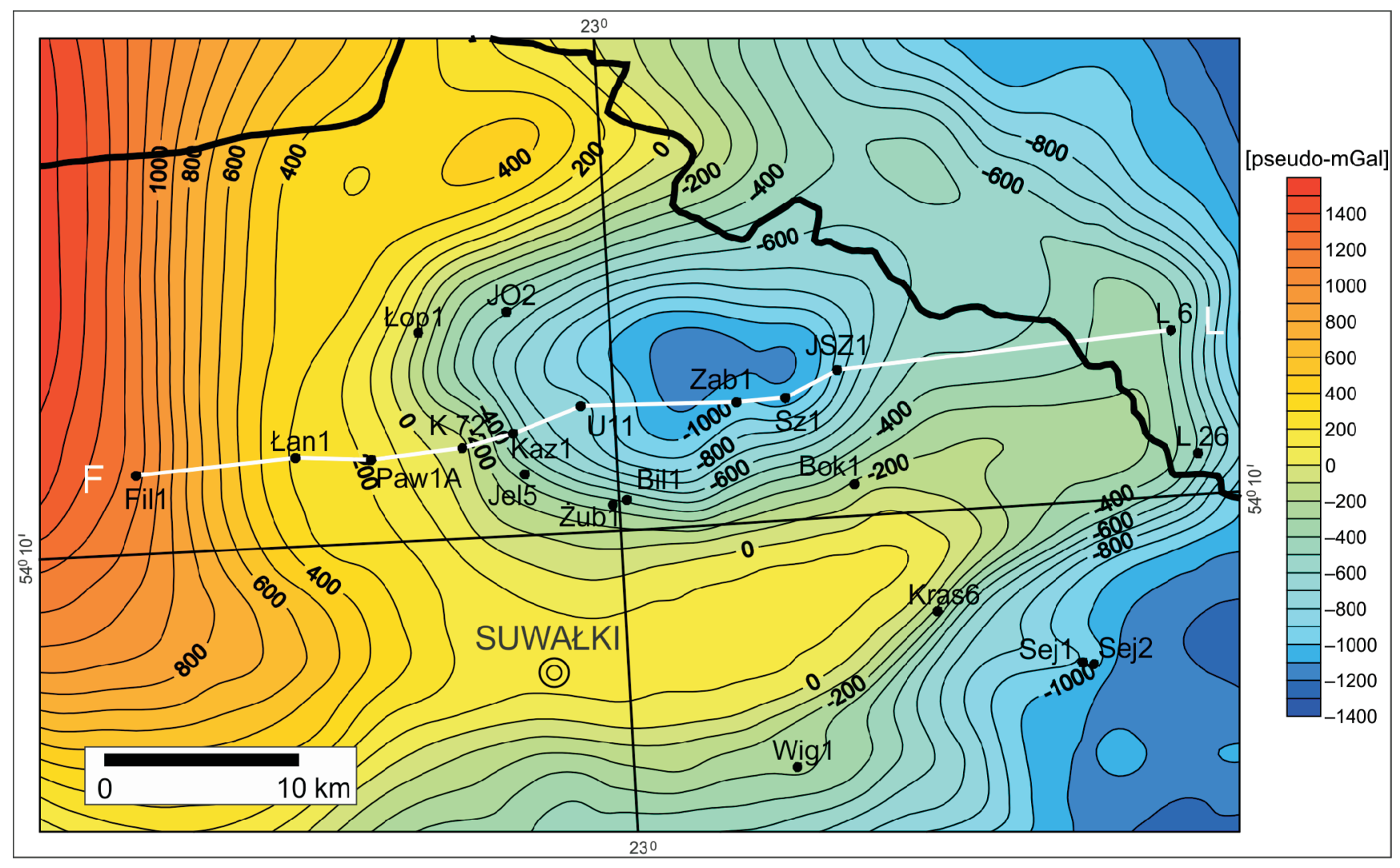

Fig. 4. Pseudogravity transformation of the magnetic anomaly map of the Suwałki Anorthosite Massif (SAM) area Explanations as in Figure 2

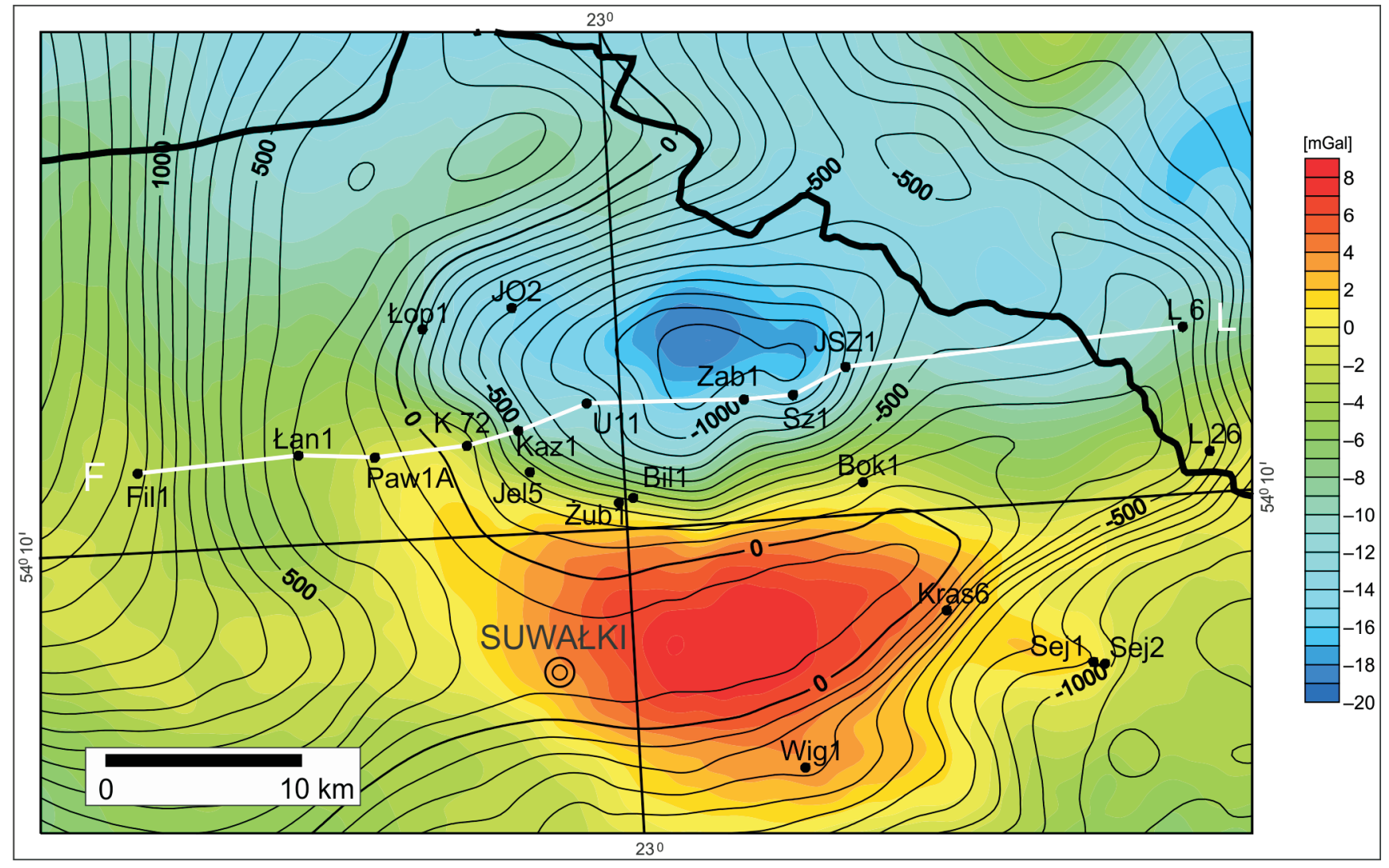

Fig. 5. Comparison of Bouguer gravity map with pseudogravity map (contours) of the Suwałki Anorthosite Massif (SAM) area Explanations as in Figure 2 


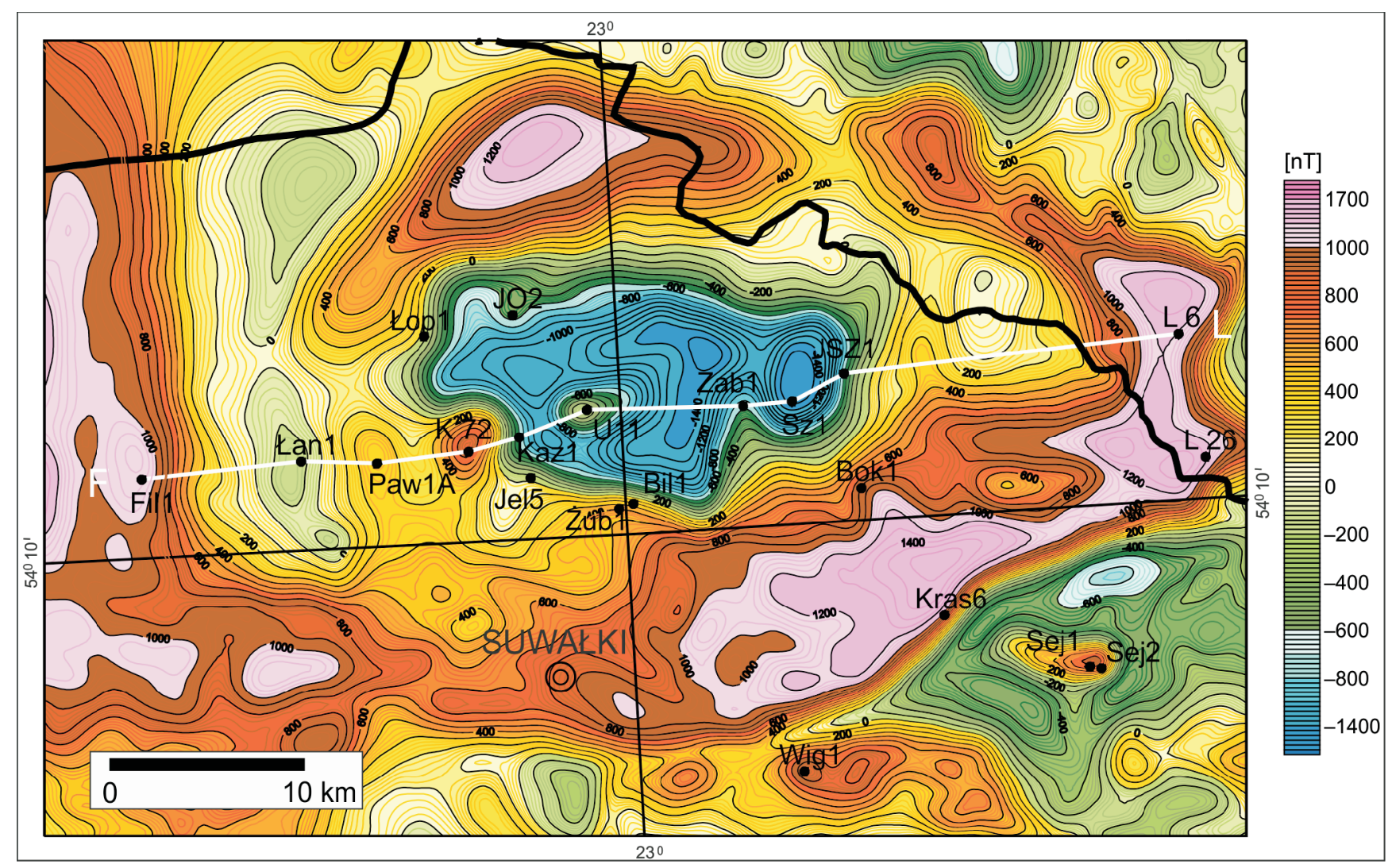

Fig. 6. Reduced to the pole total intensity magnetic anomaly map of the Suwałki Anorthosite Massif (SAM) area

Explanations as in Figure 2

The anomaly minimum related to the central anorthosite complex of the SAM shows a direct correlation with the gravity anomaly (Fig. 3). The magnetic gradients became steeper, enhancing the accurate reproduction of the structure and composition of the crystalline basement.

The reduced to the pole magnetic anomaly map is the starting point for further enhancement.

\section{REGIONAL-RESIDUAL SEPARATION OF MAGNETIC AND GRAVITY DATA}

A regional anomaly component in the magnetic and gravity fields over the SAM (Figs. 2 and 3), especially in the Bouguer gravity field, masks the relationship that exists between the shapes of the observed anomalies and the sources near to the crystalline basement. A common practice in gravity and magnetic interpretation is to separate anomalies of different horizontal extents or their wavelengths (Blakely,1995). In this case deeper sources would be associated with long wavelength (regional) anomalies while the shallower sources would be associated with short wavelength (residual) anomalies. Long wavelengths may also arise from broad shallow sources.

The radially averaged power spectra of the RTP (Fig. 6) and the Bouguer gravity (Fig. 3) anomaly maps of the SAM were computed and analysed as a guide to indentify the wavenumber (=1/wavelength) content of these maps and to the design of operators for regional-residual separation (Spector and Grant, 1970).

The regional and residual wavenumber domains were defined in the graphs of the natural logarithm of the radially aver- aged magnetic and gravity power spectra versus the radial wavenumber (Fig. 7) based on the slopes of the spectra (Spector and Grant, 1970).

Both of the power spectra show a pronounced change in slope at wavenumber of $\sim 0.08 \mathrm{~km}^{-1}$ (corresponding to a wavelength of $12.5 \mathrm{~km}$ ), clearly separating two domains associated with the regional and residual anomalies. The first of these corresponds to wavenumbers of up to $0.08 \mathrm{~km}^{-1}$ for both magnetic data and gravity data. The second one corresponds to wavenumbers $>0.08 \mathrm{~km}^{-1}$. The regional and residual data sets were then calculated using a Butterworth filter with cut-off wavenumber $0.08 \mathrm{~km}^{-1}$. In addition, the residual gravity anomaly map was smoothed by excluding that portion of the spectrum beyond the wavenumber $0.5 \mathrm{~km}^{-1}$ (corresponding to a wavelength of $2 \mathrm{~km}$ ) to remove short wavelength anomalies, which arise from very shallow gravity sources, station errors, and so on.

Separating the regional from the residual signals allows construction of particular magnetic and gravity maps that highlight regional structures in the upper crust (Fig. 8) or depict local structures in the top of the crystalline basement (Fig. 9).

Residual magnetic (Fig. 9A) and gravity (Fig. 9B) anomaly maps are most appropriate for high-resolution mapping of the crystalline basement top. A number of distinct anomalies occur within the survey area, both positive and negative, related to the different groups of intrusive rocks. Moreover, the obvious similarity of the magnetic and gravity signatures can be seen from these figures. In both residual fields, the central anorthosite complex is marked as a negative anomaly which delineates the area of this intrusion. Their outlines are largely similar on both maps. Some of the larger known basement features like the 

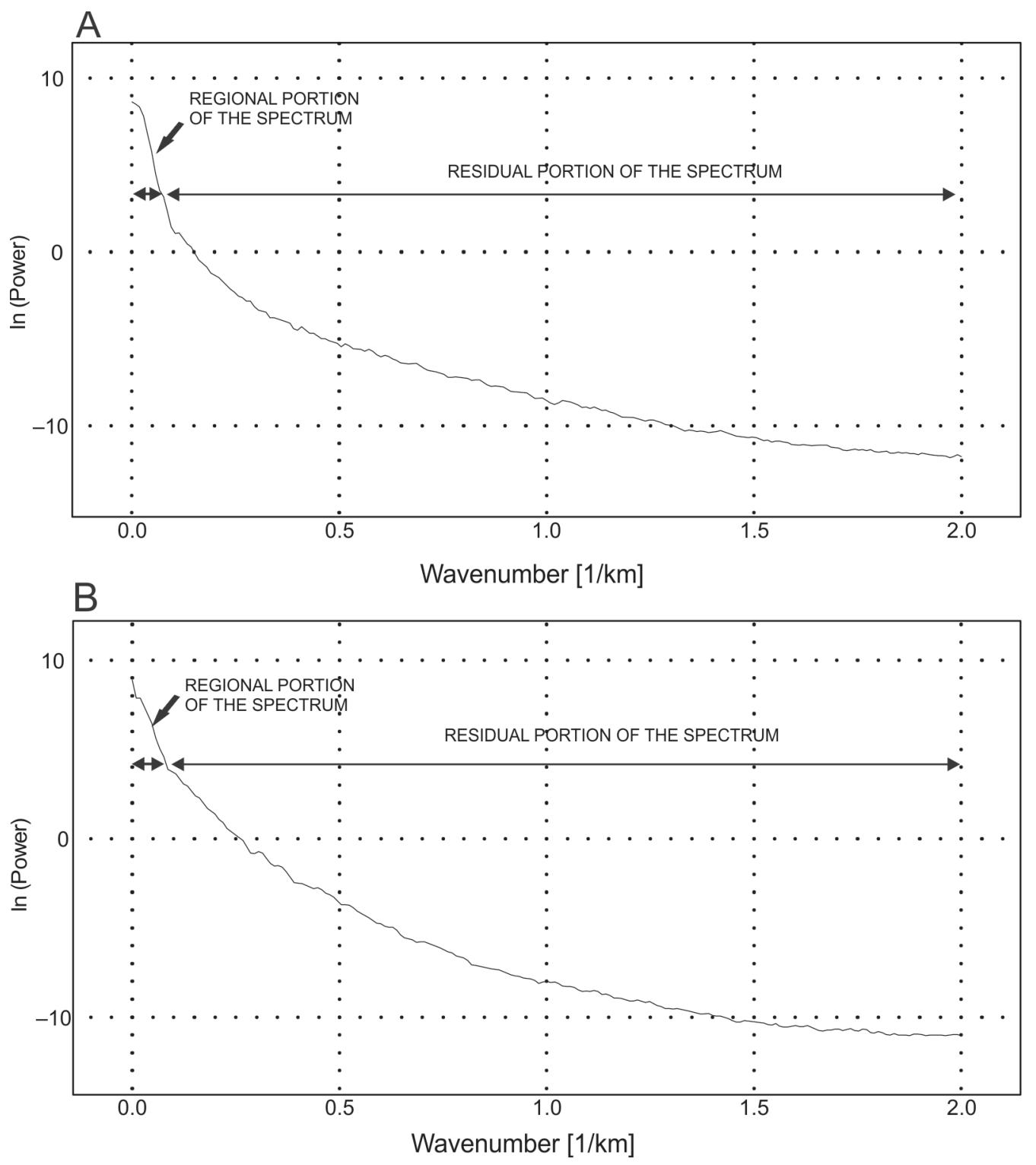

Fig. 7. The graph of the natural logarithm of radially averaged power spectrum against radial wavenumber for: A - RTP magnetic data; B - gravity data from the Suwałki Anorthosite Massif (SAM) area

Krzemianka (K), Udryn (U), Sejny (SI) and Zaboryszki (Z) positive anomalies are strongly outlined (Fig. 9).

The central anorthosite body is encircled by positive and negative anomalous marginal belts. The changes from negative to positive values in residual magnetic and gravity is roughly coincident and may be attributed to variation in composition of the basement rocks.

The predominantly positive zones are related to norites (Jel5), gabbronorites (Żub1) and diorites (Łop1, Zab1), whereas others are predominantly negative, related to charnockites (Łan1) or gneisses (Wig1).

There is a close spatial correlation between the Krasnopol (Kras6) magnetic lineament associated with the southern margin of the SAM and the gravity gradient obtained by the high-pass filtration of Bouguer gravity data.

\section{JOINT MODELING OF GRAVITY AND MAGNETIC DATA}

The joint modeling of gravity and magnetic fields was carried out along the Filipów IG 1 (Fil1)-Lazdiai 6 (L6) (F-L) profile (Figs. 2 and 3 ) to further investigate the tectonic relationship of the central anorthosite complex with the surrounding basement domains. The profile runs across the centre of the intrusion and is well constrained by data from several boreholes.

The model was constructed using GM-SYS2D software by GEOSOFT Oasis Montaj, which generates the magnetic and gravity response from a geological model. The model is $2.75 \mathrm{di}-$ mensional i.e. it can contain some bodies that have limited and/or asymmetric strike extent off-the-section. This is an important option in the modeling process since the gravity and magnetic anomalies are asymmetrical with respect to the profile location. 


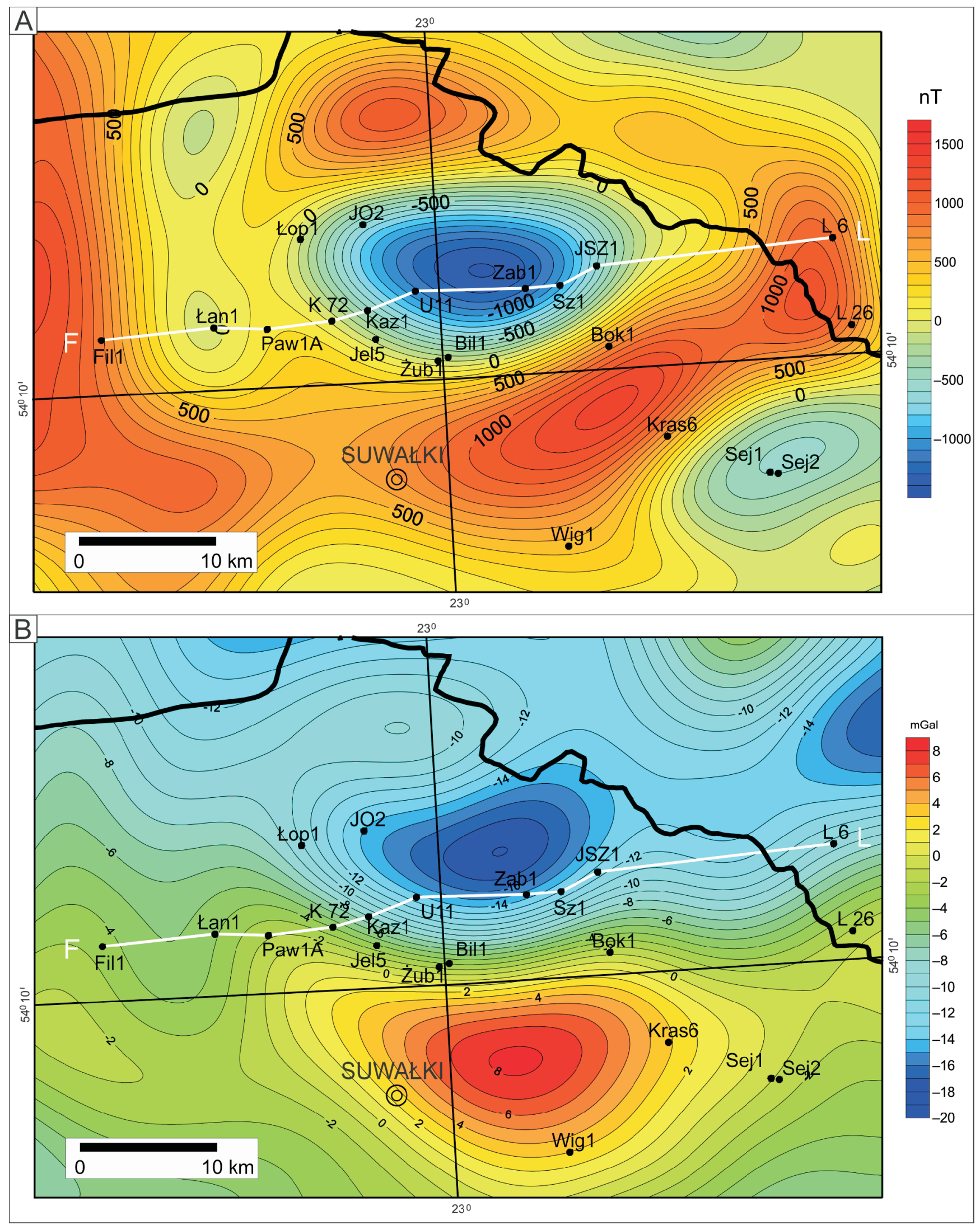

Fig. 8. Regional RTP anomaly map (A) and regional gravity anomaly map of the Suwałki Anorthosite Massif (SAM) area (B) Explanations as in Figure 2 

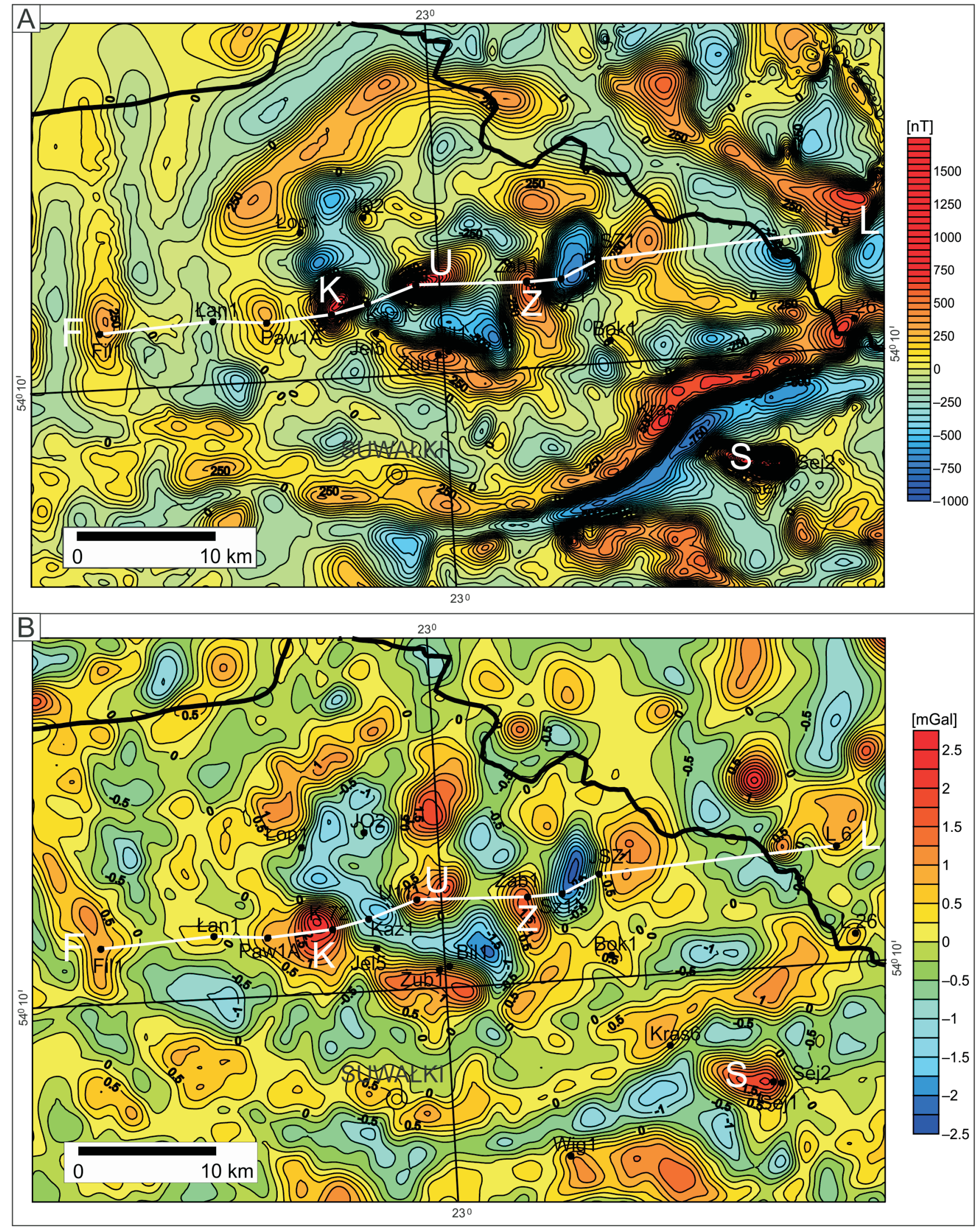

Fig. 9. The residual RTP anomaly map (A) and residual gravity anomaly map of the Suwałki Anorthosite Massif (SAM) area (B) $\mathrm{K}, \mathrm{U}, \mathrm{S}, \mathrm{Z}$ - positive magnetic and gravity anomalies mentioned in the text; other explanations as in Figure 2 

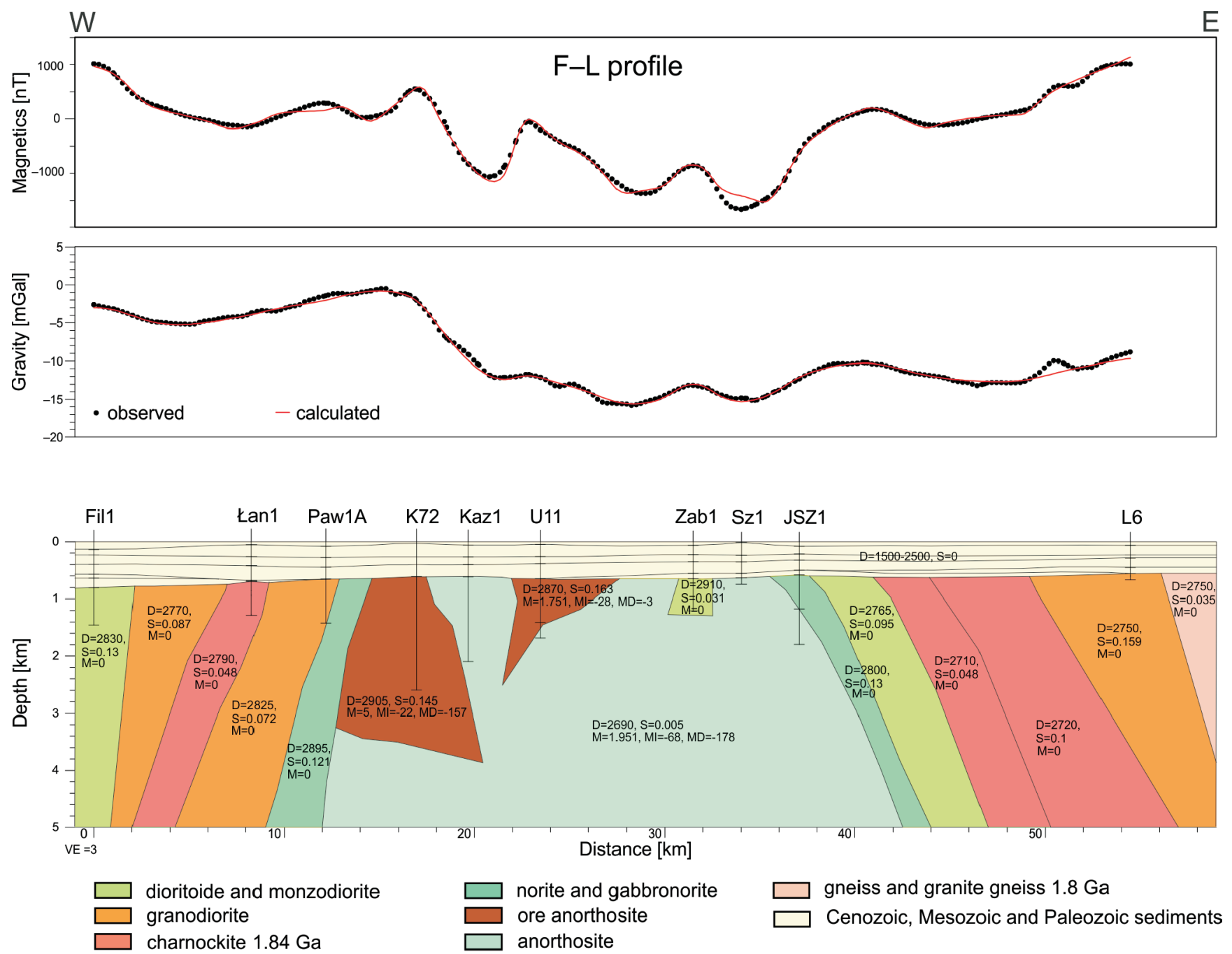

Fig. 10. 2.75D gravity and magnetic model along profile F-L with location shown on maps in Figures 2 to 6 and 8 to 9

$\mathrm{D}$ - density in $\mathrm{kg} / \mathrm{cm}^{3}, \mathrm{~S}$ - magnetic susceptibility in SI units, $\mathrm{M}$ - remanent magnetization in $\mathrm{A} / \mathrm{m}, \mathrm{MI}$ - remanent inclination in degree, $\mathrm{MD}$ - remanent declination in degree; other explanations as in Figure 2

The initial geological model was constructed using the borehole data. The geological concept of the structure of the SAM was also considered. Modeling was carried out using density and magnetic property data assigned for bodies representing different rock units. The main Phanerozoic sedimentary rock cover packages were associated with different densities, between 1500 and $2500 \mathrm{~kg} / \mathrm{m}^{3}$, which were kept fixed during modeling. The sedimentary rocks were considered to have null magnetic susceptibility, and the sources of the magnetic anomalies were attributed to the crystalline basement rocks. The bottom surface of the modeled polygons was assumed to be $5 \mathrm{~km}$, to satisfy the regional gravity and magnetic effects of the SAM.

The model was then progressively changed by interactively adjusting the shape of the bodies or their properties until a good fit to both the gravity and magnetic fields was obtained. However, given the susceptibility and NRM scatter within the rock property dataset, these parameters were chosen considering that they should be in the typical range for Precambrian crystalline rocks (Clark, 1997). The resulting model is illustrated in Figure 10. This is the first published model of the SAM that incorporates both magnetic and gravity data integrated with geological information.
Joint magnetic and gravity modeling helped greatly in delineating the location and extent of the anorthosite complex in the central part of the profile. This body is explained by a thick upper crustal body of density $2690 \mathrm{~kg} / \mathrm{m}^{3}$, low susceptibility $(0.005 \mathrm{SI})$ and remanent magnetization $(1.95 \mathrm{~A} / \mathrm{m})$, directed antiparallel (inclination $\mathrm{I}=-68^{\circ}$, declination $\mathrm{D}=-177^{\circ}$ ) to the present Earth's magnetic field. The prominent local magnetic anomalies in this area are related to the Krzemianka and Udryn ore anorthosites and the Zaboryszki dioritoide. The ore anorthosites have been modeled as bodies with high densities, magnetic susceptibilities and substantial remanent magnetizations.

Lateral heterogeneity across the margins of the anorthosite complex is apparent from the crustal model (Fig. 10). The presence of different rock units is reflected in the magnetic and gravity highs and lows. These gently dipping units show a wide range of physical properties, reflecting variation in the composition of the crystalline basement rocks. According to the geological data, the rocks bordering the central anorthosite body consist of norite and gabbronorite, granodiorite, diorite and charnockite. 


\section{GEOLOGICAL MAP FROM INTEGRATED MAGNETIC, GRAVITY AND GEOLOGICAL DATA}

The geological architecture of the SAM and its surrounding area was not fully and unambiguously interpreted on the basis of the former geophysical data interpretation. For this reason several analytical techniques, such as pseudogravity, reduction to the pole, spectral analysis, low-pass and high-pass filtering, and $2.75 \mathrm{D}$ modelling have been applied to process the magnetic and gravity data, to understand the distribution of the crystalline basement sources.

Results from magnetic and gravity data analyses, correlated with the revised geology of the area, were used to make a new geological map for the SAM area. For this purpose, the study area was divided into several domains with consistent magnetic and gravity patterns and more or less distinct boundaries deduced from the anomaly maps (Figs. 3, 6 and 9). The results obtained were integrated with the available borehole evidence and expected geology. Using the data obtained, a basement geological map of the craton top for the SAM area was constructed (Fig. 11).

The main, central part of the SAM consists of homogeneous anorthosite rocks, composed primarily of $80-95 \%$ of andesine-labradorite plagioclase, followed by orthopyroxene, clinopyroxene, Ti-magnetite and ilmenite. Apatite, spinel and titanite are accessory minerals (Juskowiak, 1998) as well as sulphides (Wiszniewska, 1998a). The size of plagioclase crystals in the anorthositic rocks varies in different parts of the massif. Large plagioclase crystals with visible polysynthetic twinning are crowded with minute needles of rutile, Fe-Ti oxides and antiperthite exsolutions. They are common in the marginal part of the anorthosite complex, e.g. by the Jeleniewo IG 5 (Jel5) borehole and others drilled into that margin. In the Krzemianka ore field they occur in the upper part of the basement. Medium grained anorthosites build the core of the massif. Norites and gabbronorites at the massif margins and granodiorites, diorites and charnockites bordering the massif constitute a group of rocks that are characteristic of the AMCG suite worldwide (Anderson, 1966; Emslie, 1978, 1991; Frost et al.,1989; Ashval, 1993; Emslie et al. 1994; Hamilton, 2004; Duchesne et al., 2010; Scoates et al., 2010; Vander Auwera et al., 2011; Heinonen et al., 2015).

Titanomagnetite ores are closely associated with the central anorthosites and they have been called ore anorthosites on the map legend. The Fe-Ti-V ores (ferrolites) have only been confirmed in areas of localized positive anomalies in the region of the Krzemianka, Udryn, Jeleniewo and Jezioro Okrągłe ore fields. In drilled sections, Fe-Ti-V ores as titanomagnetie, pure ilmenite and pleonaste minerals form numerous interlayered streaks, a few millimetres thick, schlieren of several centimetres-scale, complex veins or lenses, pseudobeds and irregular bodies from several to over a thousand meters thick e.g. Krzemianka 72 borehole (K72). Ore bodies distinctly border host rocks, while smaller structures such as schlieren, nests and impregnations have gradual contacts with the host anorthosite rocks (Speczik et al.,1988). In the marginal part of the Krzemianka ore field and in some Udryn logs, e.g. Udryn IG 11 (U11), and Jeleniewo IG 5 (Jel5), dispersed hematite-ilmenite and pure magnetite mineralization has also been observed (Wiszniewska, 1998b).

The norites and gabbronorites have similar mineral compositions, only differing in the ortho- and clinopyroxene ratio and opaque minerals content. They are shown together on the map legend. Norites are fine grained, usually with directed fabric e.g. Jezioro Szlinokiemskie PIG 1 (JSZ1). They contain about 5-32\% opaque minerals (Juskowiak, 1998). Gabbronorites, un- like the norites, are coarser grained with a higher opaque minerals content. They contain both pyroxenes, titanite, apatite and Fe-Ti oxide grains e.g. in Bilwinowo PIG 1 (Bil1).

Gabbronorites lie in along the contact with norites and anorthosites and are present in boreholes located in marginal parts e.g. Jeleniewo IG 5 (Jel5) and Biliwinowo PIG 1 (Bil1). Diorites and monzodiorites commonly overlie the gabbronorites and do not have contacts with the norites and anorthosites (Wiszniewska et al., 2002). The smaller Sejny intrusion (SI), located a few $\mathrm{km}$ to the south-east of the SAM, comprises gabbroidic rocks of $1.59 \mathrm{Ga}$ age (Fig. 11). Hypersthene monzodiorites (jotunites), gabbro and anorthosites were encountered in the Sejny IG 1 (Sej1) borehole and are indicated together on the map legend.

Diorites are coarse grained rocks, composed of $45 \%$ of plagioclase, K-feldspar (8-15\%) and quartz (8-12\%) (Juskowiak, 1998). These rocks have been drilled in a tectonic block within the SAM anorthosites in the Zaboryszki IG 1 well (Zab1), and in the Łopuchowo PIG 1 (Łop1) and Zuubryn IG 1 (Żub1) boreholes at the marginal part of the central anorthosite complex. Medium grained monzodiorites are present in the Filipów IG 1 (Fil1) borehole on the western flank of the SAM.

Granodiorites and charnockites belong chemically to the ferro-potassic, alkali-calcic type of rocks and are comparable with rock complexes in Veisiejai (V), Lithuania and in Rogaland, southern Norway (Skridlaite et al., 2003). The most acidic varieties of the granodiorites approach classic rapakivi granites in their petrogenetic characteristics, elevated contents of incompatible elements and REE, and hence have A-type affinities.

Two genetic types of charnockitic rock (orthopyroxenebearing felsic rocks), formed in a deep-seated dry environment, either under plutonic or high-grade metamorphic conditions, were found within the cover of the SAM (Bagiński and Krzemińska, 2004). Magmatic charnockites have been noted in the Bilwinowo IG 1 borehole (Bil1), as thin layers and are characterized by a metaluminous, ferroan and high $\mathrm{K}_{2} \mathrm{O}$ composition. Other types of charnockite have previously been considered as components of the AMCG suite in the Łanowicze area (Bagiński et al., 2001). Further studies revealed that the charnockites from the Łanowicze PIG 1 (Łan1) borehole represent a unique relic of pre-Mesoproterozoic crust that originated along an active continental margin. These charnockites belong to a group of metamorphic rocks that formed in part under granulite-facies conditions (Bagiński, 2006). A recent geochronological study using the U-Pb SHRIMP method revealed a composite suite of Łanowicze charnockites that were primarily crystallized at $1.84 \mathrm{Ga}$ and turned into charnockites at $1.79 \mathrm{Ga}$ (Krzemińska et al., 2019). These metamorphic charnockites were indicated on the map as a separate Paleoproterozoic component among the AMCG magmatic $1.5 \mathrm{Ga}$ suite on the western and the eastern parts of the SAM cover and around the Sejny Intrusion (SI).

Granodiorites and granites are the most widespread rock types within the AMCG affinity suite in the Pawłówka PIG 1A (Paw1A), Boksze PIG1 (Bok1) and Krasnopol PIG 6 (Kras6) boreholes. They are mostly porphyritic with 1-4 cm long plagioclase or K-feldspar phenocrysts and clots of mafic minerals. Hornblende very often replaces clinopyroxene. These rocks have been termed rapakivi-like granites by previous petrologists (Juskowiak, 1998; Ryka, 1998).

The emplacement of the widespread granite veins (pegmatite and aplite, not indicated on the map) within the SAM pluton and its cover post-date the main $~ 1.53-1.50$ Ga tectono-thermal activity in the SAM by $\sim 20-25$ My (Wiszniewska and Krzemińska, 2017). 


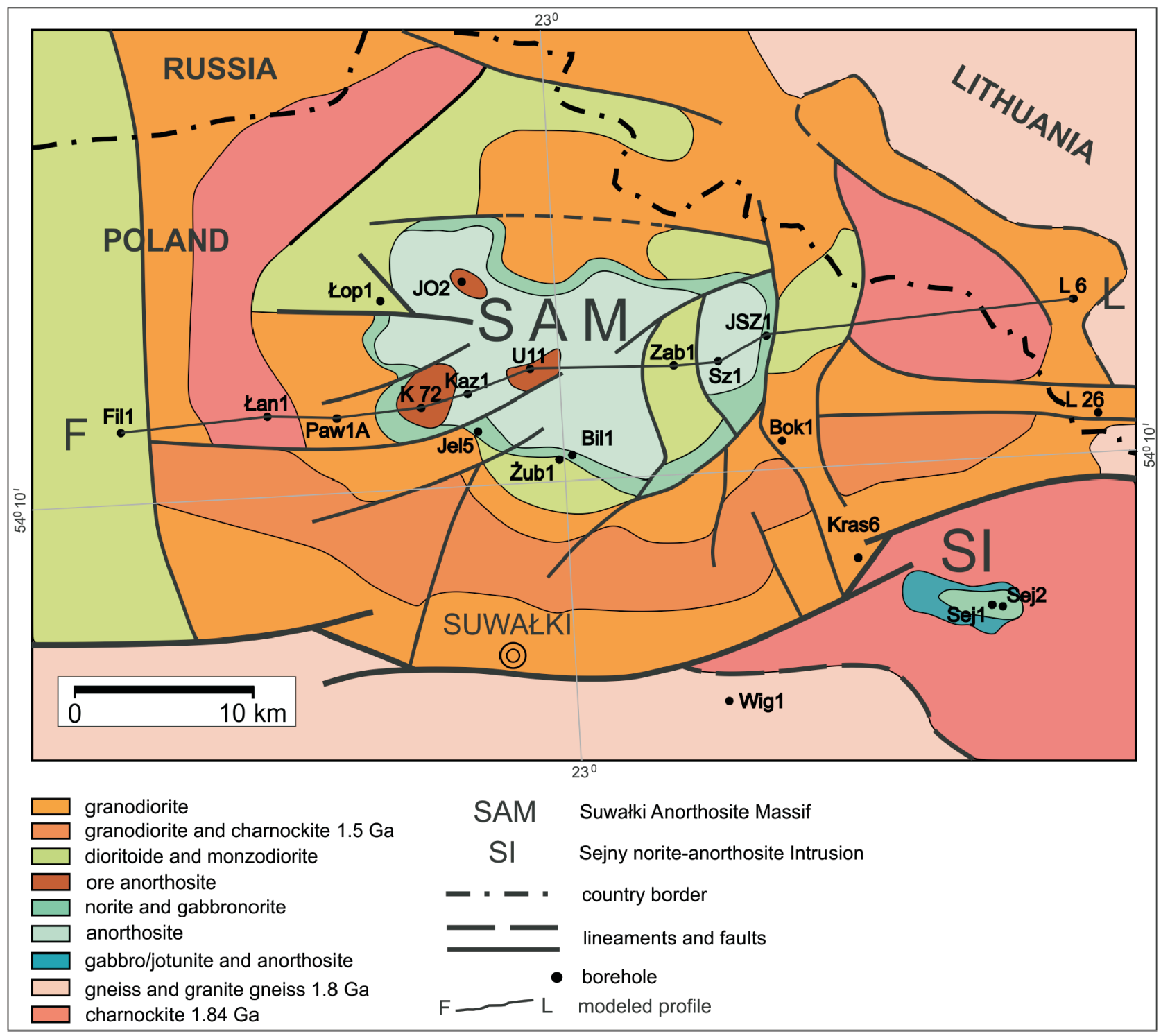

Fig. 11. New geological map of the Suwałki Anorthosite Massif (SAM) area based on integrated geophysical and geological data interpreted in this paper

Explanations as in Figure 2

Because of uneven borehole coverage, especially in the northern part of the massif, compositional variations within it could not be accurately discriminated. Nevertheless, a zonal distribution with anorthosite in the central part and the rock types noted above in the marginal parts seems clear.

\section{DISCUSSION}

The anorthosite complex of the SAM is distinctly oval in map view and produces a negative magnetic anomaly, which is difficult to explain. It has been supposed that this anomaly is a direct result of the negative inclinations of the NRM (Cieśla and Wybraniec, 1998). However, previous studies report that the magnetite-ilmenite ores (but not anorthosites) largely show negative NRM (Mizeracka and Kurbiel, 1973, 1975). The pseudogravity transformation was used to determine the direction of magnetization of the anorthosite complex (Ates and Kearey, 1995) because the effect caused by this direction may be a major problem when interpreting the magnetic anomaly data. Comparison of the Bouguer gravity map with the pseudogravity map (Fig. 5) indicates that the NRM direction is nearly antiparallel to the induced direction. Magnetic modeling also shows that the negative anomaly related to the anorthosite complex is a direct result of the negative inclination of the NRM (Fig. 10). Brown et al. (2011) demonstrated that two anorthosite complexes, Morin in southern Quebec, Canada and Rogaland in southern Norway, produce large negative anomalies over anorthosites reflecting the presence of hematite-ilmenites with low susceptibility but large NRM values and directions nearly antiparallel to the present magnetic field. Lamellar magnetization in hematite-ilmenites is an explanation for strong remanent magnetization in anorthosites (Robinson et al., 2002). Recognition of the carriers of remanence in the SAM anorthosite should be addressed in future studies.

The deep geological and tectonic structure of the SAM is not yet fully constrained. Early geological models of the SAM have been limited by the lack of sufficient borehole data on 
basement lithologies. However, several distinct magnetic and gravity anomalies have been correlated to recognized crystalline basement features. The strong remanent magnetizations of the anorthosite and ore bodies have been considered in modeling the sources of the magnetic anomalies. A new structural model reveals a system of geological rock units that explains the magnetic and gravity anomalies (Fig. 10), dominated by massif type anorthosite in the centre characterized by a large negative anomaly, surrounded by rocks with marked magnetic and density properties. Aside from anorthosite, the main rock types of the SAM include norite and gabbronorite, granodiorite, diorite and charnockite. The surface pattern of these inclined basement units probably reflects major stages of the evolution of the SAM.

The results of the present studies are summarized in new geological map (Fig. 11) showing the extent of the main basement units.

This new geophysical analysis has provided better resolved boundaries of the rock units by comparison with earlier geological maps (e.g., Fig. 1; Wiszniewska, 2002) and other papers (Kubicki and Ryka, 1982; Juskowiak, 1998; Cymerman, 2014). Recent petrological study helped recognize new genetic rock units, such as igneous and metamorphic charnockites in the Łanowicze borehole (Łan1; Bagiński, 2006; Krzemińska et al., 2019), a granodiorite belt along the Krasnopol lineament and hypersthene monzodiorites (jotunites) in the Sejny area.

The SAM has a domal structure in cross-section (Juskowiak, 1998), which is why the erosional basement surface shows an elliptical diapiric shape of the central anorthosite intrusion, surrounded by norite-gabbronorite-dioritoide-granite rims.

The high magnetic gradient zone (Krasnopol lineament) on the southern side of the map (Figs. 2, 6 and 9A), that is also visible in the residual gravity map (Fig. 9B), outlines the contact between the granodiorite in the north and the gneiss/granite gneiss and charnockites in the south (Fig. 11). This major geophysical contact is interpreted as a fault bounding the massif margin in the south. The magnetic and gravity patterns in the north are orientated parallel to the Krasnopol magnetic lineament (Fig. 9). This prominent zone separates two large geological domains of different age and genesis: the igneous Mesoproterozoic Mazury Complex (MC) of AMCG affinity of $\sim 1.5 \mathrm{Ga}$ age; and the metamorphic Paleoproterozoic Mazowsze Domain (MD) of $1.8 \mathrm{Ga}$ age in the south. This tectonic structure was interpreted earlier on magnetic maps but has never been shown as a significant deeply rooted shared zone on geological maps.

The MC is composed of porphyritic A-type granitoids, covering the range of leucogranite, quartz-monzonite, monzonite, granodiorite, monzodiorite and diorite (Bagiński et al., 2001; Skridlaite et al., 2003; Gawęda et al., 2009). In the Krasnopol IG 6 borehole (Kras6), granodiorite, monzodiorite, granite and charnockite rocks have mostly been encountered. The igneous MC intruded amphibolite and granulite-facies metamorphic rocks of the West Lithuanian and Mid-Lithuanian domains in the north-east and their southern Polish extensions (Bogdanova et al., 2015) and extends along an E-W trending shear zone that was repeatedly active over a $\sim 150$ Myr time span (1.6-1.45 Ga; Bogdanova et al., 2006). The structural setting of the MC emplacement is considered to be anorogenic (e.g., Dörr et al., 2002; Gawęda et al., 2009) or post-collisional (Duchesne et al., 2010).

\section{CONCLUSIONS}

Several filtering processes have been applied to magnetic and gravity data in the area of the Suwałki Anorthosite Massif (SAM). The resultant anomaly maps show features related to the geological and structural framework of the area. For a better understanding of the basement geology, forward modelling of the gravity and magnetic data along the selected profile was performed using information associated with geological studies. Besides providing an overall picture, the model improves geophysical and geological interpretations of the SAM rock units. Finally, a corrected geological subcrop map of the SAM top erosional surface has been prepared.

These analyses allow the following main conclusions:

1. The anorthosite complex of the SAM has a large negative anomaly, low susceptibility, and high remanence (probably related to hemo-ilmenite minerals dispersed within the anorthosites) and remanent directions antiparallel to the induction direction.

2. The residual magnetic and gravity anomaly maps enhance the internal features and their boundaries related to the different groups of intrusive rock such as anorthosite, ore-anorthosite, norite, gabbronorite, diorite, granodiorite and charnockite.

3. The first potential-field model along a profile crossing the SAM shows the overall structure of the SAM providing valuable information about the shape and extent of the core anorthosite body and petrological variations within the massif.

4. By comparison with the known geology, basement structures have been mapped by magnetic and gravity data interpretation. The new geological map based on modern geophysical calculations enables reliable and up-to date imaging of the SAM, improving and correcting earlier maps.

5. The strong Krasnopol magnetic lineament, reflected also in the residual gravity field, is the main and pronounced boundary between Mesoproterozoic and Paleoproterozoic domains: the Mazury Complex (MC) and the Mazowsze Domain (MD).

6. An understanding of the geological structure of the SAM is important for studying the formation and evolution of anorthosite massifs which are petrological and geochemical windows into the Proterozoic crust.

7. The geophysical and geological analyses presented in this paper generate targets for future mapping and enhance the potential for recognizing ore mineralization in the SAM region.

Acknowledgements. Funding of the present work was provided by the Polish Geological Institute-NRI statutory funds (project no. 62.9012.1972.00.0 for ZP) and 2015/17/B IST10/03540 grant to the second author (JW). The authors would like to thank Dr. S. Salwa for constructive discussions on the course of faults and the main tectonic structure of this intrusion and M.Sc. A. Grabarczyk from the Geology Faculty UW for her help in making the final image of the SAM geological map. The authors are grateful for detailed and important remarks from 3 reviewers: Prof. A. Gawęda, Dr. G. Skridlaite and Prof. M. Bielik, and efficient editorial handling by Prof. P. Aleksandrowski. 


\section{REFERENCES}

Anderson, A.T., 1966. Mineralogy of the Labrieville anorthosite, Quebec. American Mineralogist, 51: 1671-1711.

Ashwal, L.D., 1993. Proterozoic Massif-Type Anorthosites. In: Anorthosites (ed. L.D. Ashwal): 82-218. Springer, Heidelberg and New York.

Ates, A., Kearey, P., 1995. A new method for determining magnetization direction from gravity and magnetic anomalies: application to the deep structure of the Worcester Graben. Journal of the Geological Society, 152: 561-566.

Bagiński, B., 2006. Different ages recorded by zircon and monazite in charnockitic rocks from the Łanowicze borehole (NE Poland). Mineralogia Polonica Special Papers, 29: 79.

Bagiński, B., Krzemińska, E., 2004. Igneous charnockites and related rocks from the Bilwinowo borehole (NE Poland) - a component of AMCG suite - a geochemical approach. Polish Mineralogical Society Special Publications, 24: 69-72.

Bagiński, B., Duchesne, J.-C., Vander Auwera, J., Martin, H., Wiszniewska, J., 2001. Petrology and geochemistry of rapakivi-type granites from the crystalline basement of NE Poland. Geological Quarterly, 45 (1): 33-52.

Baranov, V., 1957. A new method for interpretation of aeromagnetic maps: Pseudogravity anomalies. Geophysics, 22: 359-383.

Baranov, V., Naudy, H., 1964. Numerical calculation of the formula of reduction to the magnetic pole. Geophysics, 29: 67-79.

Blakely, R.J., 1995. Potential Theory in Gravity and Magnetic Applications. Cambridge University Press, Cambridge.

Bogdanova, S., Gorbatschev, R., Grad, M., Janik, T., Guterch, A., Kozlovskaya, E., Motuza, G., Skridlaite, G., Starostenko, V.I., Taran, L., E.A.P.W. Groups, 2006. EUROBRIDGE: New insight into the geodynamic evolution of the East European Craton. Geological Society Memoirs, 32: 569-625.

Bogdanova, S., Gorbatschev, R., Skridlaite, G., Soesoo, A., Taran, L., Kurlovich, D., 2015. Trans-Baltic Palaeoproterozoic correlations towards the reconstruction of supercontinent Columbia/Nuna. Precambrian Research, 259: 5-33.

Brown, L.L., McEnroe, S.A., Peck, W.H., Nilsson, L.P., 2011. Anorthosites as sources of magnetic anomalies. International Association Geomagnetism and Aeronomy Special Sopron Book Series, 1: 321-342

Cieśla, E., Wybraniec, S., 1998. Geophysical studies of the Suwałki Anorthosite Massif. Prace Państwowego Instytutu Geologicznego, 161: 27-38.

Clark, D.A., 1997. Magnetic petrophysics and magnetic petrology: aids to geological interpretation of magnetic surveys. AGSO Journal of Australian Geology \& Geophysics, 17: 83-103.

Cymerman, Z., 2014. Structural and kinematic analysis and the Mesoproterozoic tectonic evolution of the Suwałki Massif and its surroundings (NE Poland) (in Polish with English summary). Prace Państwowego Instytutu Geologicznego, 201: 1-131.

Demaiffe, D., Wiszniewska, J., Krzemińska, E., Williams, I.S., Stein, H., Brassinnes, S., Ohnenstetter, D., Deloule, E., 2013. A hidden alkaline and carbonatite province of early Carboniferous age in north east Poland: zircon U-Pb and pyrrhotite Re-Os geochronology. Journal of Geology, 121: 91-104.

Dörr, W., Belka, Z., Marheine, D., Schastok, J., Valverde-Vaquero, P., Wiszniewska, J., 2002. U-Pb and Ar-Ar geochronology of anorogenic granite magmatism of the Mazury complex, NE Poland. Precambrian Research, 119: 101-120.

Duchesne, J.C., 1999. Fe-Ti deposits in Rogaland anorthosites (South Norway): geochemical characteristics and problems of interpretation. Mineralium Deposita, 34: 182-198.

Duchesne, J-C., Herve, M., Bagiński, B., Vander-Auwera, J., Wiszniewska, J., 2010. The origin of the ferroan-potassic A-type granitoids: the case of the hornblende-biotite granite suite of the Mesoproterozoic Mazury Complex, Northeastern Poland. Canadian Mineralogist, 48: 1195-1216.

Emslie, R.F., 1978. Anorthosite massifs, rapakivi granites, and the late Proterozoic rifting of North America. Precambrian Research, 7: 61-98.
Emslie, R.F., 1991. Granitoids of rapakivi granite-anorthosite and related associations. Precambrian Research, 51: 173-192.

Emslie, R.F., Hamilton, M.A., Thériault, R.J., 1994. Petrogenesis of a mid-Proterozoic anorthosite-mangerite-charnockite-granite (AMCG) complex: isotopic and chemical evidence from the Nain Plutonic Suite. Journal of Geology, 102: 539-558.

Frost, B.R., Lindsley, D.H., Simmons, C., 1989. Penrose Conference report - origin and evolution of anorthosites and related rocks. Geology, 17: 474-475.

Gawęda, A., Krzemińska, E., Wiszniewska, J., 2009. A-type granites in the Mazury Complex - contribution to world-wide discussion on granite classification (in Polish with English summary). Przegląd Geologiczny, 57: 478-485.

Grad, M., Jensen, S.L., Keller, G.R., Guterch, A., Thybo, H., Janik, T., Tira, T., Yliniemi, J., Luosto, U., Motuza, G., Nasedkin, V., Czuba, W., Gaczyński, E., Środa, P., Miller, K.C., Wilde-Piórko, M., Komminaho, K., Jacyna, J., Korabliova, L., 2003. Crustal structure of the Trans-European suture zone region along POLONAISE'97 seismic profile P4. Journal of Geophysical Research, 108: B11, ESE 12, 1-24.

Hamilton, M.A., McLelland, J., Selleck, B., 2004, SHRIMP U-Pb zircon geochronology of the anorthosite-mangerite-charnockitegranite suite, Adirondack Mountains, New York: ages of emplacement and metamorphism. GSA Memoir, 197: 337-355.

Heinonen, A., Andersen, T., Rämö, O.T., Whitehouse, M.J., 2015. The source of Proterozoic anorthosite and rapakivi granite magmatism: evidence from combined in situ $\mathrm{Hf}-\mathrm{O}$ isotopes of zircon in the Ahvenisto complex, southeastern Finland. Journal of the Geological Society, 172: 103-112.

Juskowiak, O., 1998. Occurrence, structure and mineral diversity of rocks from the Suwałki Anorthosite Massif. Prace Państwowego Instytutu Geologicznego, 161: 67-79.

Królikowski, C., Petecki, Z., 1995. Gravimetric Atlas of Poland. Polish Geological Institute, Warsaw.

Królikowski, C., Petecki, Z., Żółtowski, Z., 1998. Main structural units in the Polish part of the East-European Platform in the light of gravimetric data (in Polish with English summary). Biuletyn Państwowego Instytutu Geologicznego, 386: 5-58.

Krzemińska, E., Krzemiński, L., Petecki, Z., Wiszniewska, J., Salwa, S., Żaba, J., Gaidzik, K., Williams, I.S., Rosowiecka, O., Taran, L., Johansson, A., Pécskay, Z., Demaiffe, D., Grabowski, J., Zieliński, G., 2017. Geological Map of Crystalline Basement in the Polish Part of the East European Platform 1:1,000,000. Polish Geological Institute, Warsaw.

Krzemińska, E., Łukawska, A., Bagiński, B., 2019. U-Pb zircon geochronology of high-grade charnockites - exploration of pre-Mesoproterozoic crust in the Mazury Complex area. Acta Geologica Polonica, 69: 489-511.

Kubicki, S., Ryka, W., 1982. Geological Atlas of Crystalline Basement in Polish Part of the East-European Platform, 1:500,000. Geological Institute, Warsaw.

Kubicki, S., Siemiątkowski, J., 1979. Ore mineralization of the Suwałki basic massif (in Polish with English summary). Biuletyn Państwowego Instytutu Geologicznego, 316: 5-136.

Kurbiel, H., Siemiątkowski, J., Subieta, M., 1979. The results of geophysical-geological surveys of the Suwałki region (north-eastern Poland) (in Polish with English summary). Kwartalnik Geologiczny, 23 (1): 87-101.

Mizeracka, K., Kurbiel, H., 1973. Relation between magnetic properties and rock composition of the Suwałki anorthosite intrusive (in Polish with English summary). Kwartalnik Geologiczny, 17 (4): 683-699

Mizeracka, K., Kurbiel, H., 1975. Relation between magnetic properties and mineral composition of rocks from the Suwałki anorthosite massif. Publications of the Institute of Geophysics, Polish Academy of Sciences, 82: 157-169.

Parecki, A., 1998. Geological structure of the Krzemianka and Udryn deposits. Prace Państwowego Instytutu Geologicznego, 161: 123-136. 
Petecki, Z., 2006. Integrated gravity and magnetic modeling along P4 seismic profile (in Polish with English summary). Prace Państwowego Instytutu Geologicznego, 188: 77-87.

Petecki, Z., Rosowiecka, O., 2017. A new magnetic anomaly map of Poland and its contribution to the recognition of crystalline basement rocks. Geological Quarterly, 61 (4): 934-945.

Podemski, M., 1998. Discovery and exploration of the Suwałki Anorthosite Massif: a case history. Prace Państwowego Instytutu Geologicznego, 161: 7-18.

Robinson, P., Harrison J.R., McEnroe, S.A., Hargraves, R., 2002. Lamellar magnetism in the hematite-ilmenite series as an explanation for strong remanent magnetization. Nature, 418: 517-520.

Ryka, W., 1998. Views on the origin of the Suwałki Anorthosite Massif. Prace Państwowego Instytutu Geologicznego, 161: 161-169.

Ryka, W., Podemski, M. (eds.), 1998. Geology of the Suwałki Anorthosite Massif (northeastern Poland). Prace Państwowego Instytutu Geologicznego, 161.

Scoates, J.S., Lindsley, D.H., Frost, B.R., 2010. Magmatic and structural evolution of an anotherositic magma chamber: the Poe Mountain intrusion, Laramie anorthosite complex, Wyoming. Canadian Mineralogist, 48: 851-885.

Skridlaite, G., Wiszniewska, J., Duchesne, J.-C., 2003. Ferro-potassic A-type granites and related rocks in NE Poland and S Lithuania: west of the East European Craton. Precambrian Research, 124: 305-326.

Spector, A., Grant, F.S., 1970. Statistical models for interpreting aeromagnetic data. Geophysics, 35: 293-302.

Speczik, S., Wiszniewska, J., Diedel, R., 1988. Minerals, exsolution features and geochemistry of $\mathrm{Fe}-\mathrm{Ti}$ ores of the Suwałki district (North-East Poland). Mineralium Deposita, 23: 200-210.

Szewczyk, J., 2017. The deep-seated lowland relict permafrost from the Suwałki region (NE Poland) - analysis of conditions of its development and preservation. Geological Quarterly, 61 (4): 845-858.

Taran, L., 2005. Gabbro-diorite-granodiorite-granite assemblage in Precambrian of NW Belarus. Mineralogical Society of Poland. Special Papers, 26: 85-89.

Vander Auwera, J., Bolle, O., Bingen, B., Liégeois, J.P., Bogaerts, M., Duchesne, J.C., DeWaele, B., Longhi, J., 2011.
Sveconorwegian massif-type anorthosites and related granitoids result from post-collisional melting of a continental arc root. Earth-Science Reviews, 107: 375-397.

Wiszniewska, J., 1998a. Mineralogy of the Fe-Ti-V ores of the Suwałki Anorthosite Massif. Biuletyn Państwowego Instytutu Geologicznego, 161: 137-148.

Wiszniewska, J., 1998b. Udryn (in Polish). Profile Głębokich Otworów Wiertniczych Państwowego Instytutu Geologicznego, 90: 1-150.

Wiszniewska, J., 2002. Age and genesis of Fe-Ti-V ores and related rocks in the Suwałki Anorthosite Massif (northeastern Poland) (in Polish with English summary). Biuletyn Państwowego Instytutu Geologicznego, 401: 1-96.

Wiszniewska, J., Krzemińska, E., 2017. Peraluminous vein granites from the Suwałki Anorthosite Massif and their tectonic significance - evidence from zircon age study by SHRIMP Ile/MC. Mineralogia - Special Papers, 47: 40.

Wiszniewska, J., Claesson, S., Stein, H.J., Auwera, J.V., Duchesne, J.C., 2002. The NE Polish anorthosite massifs: petrological, geochemical and isotopic evidence for a crustal derivation. Terra Nova, 14: 451-460.

Wiszniewska, J., Kusiak M.A., Krzemińska, E., Dörr, W., Suzuki, K., 2007. Mesoproterozoic AMCG granitoids in the Mazury Complex, NE Poland - a geochronological update. AM Monograph, 1: 31-39.

Wiszniewska, J., Krzemińska, E., Rosowiecka, O., Petecki, Z., Ruszkowski, M., Salwa, S., 2018. New results of polymetallic, PGE and REE mineralization research in the Suwałki Anorthosite Massif (NE Poland) (in Polish with English summary). Biuletyn Państwowego Instytutu Geologicznego, 472: 271-284.

Wiszniewska, J., Petecki Z., Krzemińska, E., Grabarczyk, A., Demaiffe, D., 2020. The Tajno ultramafic alkaline-carbonatite massif, NE Poland: a review. Geophysics, petrology, geochronology and isotopic signature. Geological Quarterly, 64 (2): 402-421.

Wybraniec, S., Cieśla, E., Petecki, Z., 1993. Badania geofizyczne obszaru suwalskiego (in Polish). Przewodnik LXIV Zjazdu PTG na Ziemi Suwalskiej: 7-15.

Znosko, J., 1993. Jak odkryto suwalskie magnetyty (in Polish). Przegląd Geologiczny, 41: 552-558. 